\title{
Factors influencing purchase intention towards consumer-to-consumer e-commerce
}

\author{
M. Dachyar(D), Liska Banjarnahor(D) \\ Department of Industrial Engineering, Universitas Indonesia (Indonesia) \\ mdachyan@yaboo.com, liska.kristin@,gmail.com
}

Received July, 2017

Accepted November, 2017

\section{Abstract}

Purpose: This study explores factors that influence consumer's purchase intention at three consumer-to-consumer (C2C) e-commerce companies in Indonesia.

Design/methodology: 5 Expert opinions are used to determine the indicators of each factor and the Structural Equation Modelling (SEM) method is used to analyze the empirical data of 400 respondents for each company.

Findings: It is found different significant factors that influence customer's purchase intention in each company. Trust and risk are found to be significantly effect purchase intention in Company A. Meanwhile, the other two companies, perceived usefulness proved to be significant in Company B and benefit significantly effect consumer purchase intention in Company C.

Originality/value: This study represents purchase intention in the consumer-to-consumer ecommerce by investigating three case study using technology acceptance model as a guiding theory.

Keywords: E-commerce, Consumer-to-Consumer, Purchase Intention, Structural Equation Modelling (SEM), Information system

Jel Codes: L81, L86, D12 


\section{Introduction}

Indonesia becomes the first country with the highest transaction of e-commerce at South East Asia Area in 2016 with $\$ 245.86$ billion in sales (eMarketer, 2016) and it is expected to grow in the following years (Statista, 2016). The e-commerce popularity also supported from the fact that three of ecommerce C2C (Consumer-to-Consumer) website has become the most visited websites in 2017 (ecommerceIQ, 2017). The increasing popularity of e-commerce C2C also brings positive influences for the growth of Small-Medium Entreprises (SME) in Indonesia. Through C2C websites, individual sellers or SME have opportunities to broaden their distribution network and their market. Based on this mutual relationship, e-commerce $\mathrm{C} 2 \mathrm{C}$ along with the involvement of SME could increase both of their sales.

Regardless of the benefit that e-commerce C2C offers and its positive effects on SME growth, hesitation of consumers to transact on the e-commerce websites still exist. The hesitations to transact are caused by the deception cases during online shopping and consumer also unable to try the product directly (Razdan, 2014). The emerging issues of trust on online shopping are occurring since the consumers unable to directly verified the products compare to direct transaction. Especially, in C2C Ecommerce, the platform usually play a mediating the role between sellers and buyers, customer's trust will be important in order to increase purchase intention (Kwahk, Ge \& Park, 2012). Also, the previous study argues that trust is one of the important factors in e-commerce significantly which affects customer purchase intention (Chen \& Ching, 2013).

Consumers' hesitation to purchase which arise from various problems in online shopping become an obstacle to the e-commerce growth. Therefore, a better understanding of purchase intention is essential for effective e-commerce usage, especially to know the customer's perspective towards C2C ecommerce and to understand consumer behavior to improve the company's business. This research investigates the success of $\mathrm{C} 2 \mathrm{C}$ e-commerce from their ability to create purchase intention of the users to shop online. This study has a purpose to obtain factors influencing purchase intention of consumers in $\mathrm{C} 2 \mathrm{C}$ e-commerce websites by investigating three $\mathrm{C} 2 \mathrm{C}$ e-commerce companies in Indonesia.

\section{Literature review}

The intention to transact or purchase intention is defined as the intention of buyers to engage in the exchange relationship at shopping websites, such as sharing information, maintain business 
relationships, and create business transactions (Zwass, 1998). Intention to purchase online is based on the relationship between behavioral intention and actual behavior. Behavioral intention of individual to do action will determine the actual individual behavior. Thus, purchase intention to particular online shopping websites is a factor that predicts the actual behavior or the purchase decision of customers (Kim, Ferrin \& Rao, 2008). The research observing online purchase intention is an appropriate measurement for intention to use the website because online transaction involves sharing information process and actual purchase so that online purchase intention will depend on many factors (Pavlou, 2003).

\subsection{Technology Acceptance Model (TAM)}

Technology Acceptance Model theory was developed at 1989 by Davis which has a purpose of predicting the acceptance of system and behavior of users when using the system. TAM explains that individual behaviour when using a system is affected by perceived ease of use and perceived usefulness. (Davis, 1989). Previous studies also using technology acceptance model as a guiding theory such as in the field of online banking information systems acceptance (Chandio, Abbasi, Nizamani \& Nizamani, 2013) and cloud computing adoption by companies (Dachyar \& Prasetya, 2012) which both of the research area related to technology adoption.

A website, in general, can be considered as an information system which give informations to its users. (Shih, 2004). Nowadays, TAM is the most suitable theory in order to explain the acceptance of technology in the information system research (Gefen, Karahanna \& Straub, 2003). Thus, online purchase intention, as an appropriate measurement for intention to use a website, should be explained as a part of technology acceptance model.

As guiding theory in this research, the two factors of TAM (perceived usefulness perceived ease of use) are included. Perceived ease of use is explained to an extent when a user experienced a particular website as easily operated and effortless (i.e., time and energy) to learn using the website (Chen \& Ching, 2013). When websites interfaces are easy to use, buyers will find the meaningful and useful information easily, which improve their perception of usefulness.

Therefore, we hypothesized:

H1: Perceived ease of use positively affects custmer's perceived usefulness in C2C e-commerce 
In the terms of e-commerce, usefulness is defined as an extent to how an online store provides helpful information to their customers and how those information help their transactions (Chen \& Ching, 2013). In online shopping, the interactions between online shoppers and online stores only happen through the websites interfaces which means an easy to understand or high perceived ease-of-use websites will lead to the creation of trust and lower misunderstanding (Blau, 1989). The previous study also found that perceived ease of use affects customer trust through customer satisfaction in telecommunication company (Dachyar \& Hananto, 2014). In the e-commerce context, it is found that the more usable and navigable a website is, the more a buyer will conclude that the online store operates in good faith, hence increasing customer's perception of trust (Chen \& Ching, 2013). Therefore, we hypothesized that:

\section{H2: Perceived ease of use positively affects customer's trust in C2C e-commerce}

According to empirical results of TAM in the previous study, perceived usefulness and perceived ease of use of the potential adopters of an information system will affect their behavioral intentions to use certain technologies (Hongyao, 2013). The previous study also shows that there is a positive relationship between perceived ease-of-use and perceived usefulness with purchase intention in technology adoption settings. In another hand, a web interface which facilitating the transaction process and easy to use website is likely to be accepted by e-commerce users (Dishaw \& Strong, 1999). Thus, we hypothesized that:

H3: Customer's perceived ease of use positively affects the customer's purchase intention in C2C e-commerce

Usefulness on its original definition is defined as an extent to which a person believes that using particular system would enhance users performance (Davis, 1989). In this study, we propose that the more customers find online transactions become useful, the more they tend to find the benefits of it compare to direct transaction. Also, online transactions enable customers to accomplish their shopping task more quickly than a traditional transaction. Hence, we hypothesized that:

H4: A consumer's perceived usefulness affects consumer's perceived benefits in C2C e-commerce

In accordance with the original TAM model, perceived usefulness is corresponded with user attitude towards information system and its use. For e-commerce context, perceived usefulness is defined as an 
extent to which an individual believes that trading on the websites would increase the effectiveness of shopping (Shih, 2004). In the previous study also shows that useful information and facilitation to assist buyer for completing the transaction will give positive values to customers which increase customer purchase intention. (Chen \& Ching, 2013). Thus, we hypothesized that:

\section{H5: Perceived usefulness positively affects the customer's purchase intention in C2C e-commerce}

\subsection{Benefit}

Benefit defined as the extent to a customer will gain advantage from the online transaction with a certain website. Internet consumers report that they purchase on the web because they perceived benefits (e.g., increased convenience, cost savings, time savings, varieties of product to choose) compared to the traditional mode of shopping (Margherio, 1998). When consumers gain benefits during online transaction with certain websites, they are more likely will make online transactions. Hence, we hypothesized that:

H6: Perceived benefit affects customer's purchase intention in C2C e-commerce

\subsection{Trust}

Trust is defined as an extent to personal guarantees that the online shop will fulfill their obligations, will behave as expected, and put attention to their customers. For e-commerce context, the responsibilities of the vendors are to provide helpful information and facilitate customers to accomplish their task successfully. Finally, online shoppers will perceive its usefulness by receiving the benefits, such as gaining information from the websites and meet their expectations when an online website can be trusted, (Chen \& Ching, 2013). Thus, the next research hypothesis is as follows:

\section{H7: A customer's trust positively affects customer's perceived usefulness in C2C e-commerce}

Trust also defined the level of confidence of a person has in his or her expectations of what other people will do in the future based on previous interaction. The importance of trust is increasing because there is a high level of uncertainty and risk occurs in the online transaction. Lack of trust is 
also the main reason why customers do not want to engage in the e-commerce. (Kim et al., 2008). Therefore, we hypothesized that the increase of trust would directly affect purchase intentions.

\section{H8: A customer's trust positively affects purchase intention in C2C e-commerce}

\subsection{Risk}

Perceived risk is an important factor that is likely to affect consumer behavior (Javernpaa, Tractinsky \& Vitale, 2000). Risk is defined as a consumer's belief of uncertainty related to the potential outcomes that might occur in the online transaction (Kim et al., 2008). In the e-commerce context, behavioral uncertainty and related risks with the possibility that a web retailer might treat their customer opportunistically will be reduced by trust. Purchaser have a tendency that a trusted web retailer will not take advantages opportunistically (Gefen, 2000). Hence, trust will reduce the perceived risk (Mayer, Davis \& Shoorman, 1995). At the point when a web retailer can be trusted to demonstrate capability, trustworthiness, and benevolence, there is less risk engaged with it. (Pavlou, 2003). Therefore, we hypothesized that:

H9: Trust affects consumer's perceived risk. in C2C e-commerce

It is basic for a purchaser who is making an online shopping to be hesitant to buy on the web when they aware of risk that might be overwhelming when contrasted with the conventional method of shopping because of the fact that the apparent of risk will build contrasted with the immediate transaction. Consequently, it should not be surprising that customers will be mindful of risk in online transaction, and such risk may impact their choices whether to buy from an online selle r. (Kim et al., 2008). Based on the arguments, we hypothesized that:

H10: Perceived risk positively affects consumer's purchase intention in C2C e-commerce

\subsection{Reputation}

Reputation is an extent to which a purchaser feel confident that a seller is being honest and care for its customers. Companies with a good reputation will be reluctant to jeopardize their reputation by acting opportunistically (Javernpaa et al., 2000). Positive reputation of the seller has been viewed as a key 
factor for diminishing risk and creating trust since it gives suspicions that the sellers have met their commitments toward different purchasers on the past. Therefore it is hypothesized that:

H11: Reputation positively affects customer's trust in C2C e-commerce

\subsection{Familiarity}

Familiarity is a "precondition or prerequisite of trust" (Luhmann, 1979) since familiarity prompts an understanding of an entity's present activities while trust manages convictions around an entity's future activities (Gefen, 2000). Familiarity related to the purchaser's level of comprehension of pertinent methods, for example, looking for items and data and requesting through sites interface. (Kim et al., 2008). Therefore it is hypothesized that:

H12: Familiarity positively affects customer's trust in C2C e-commerce

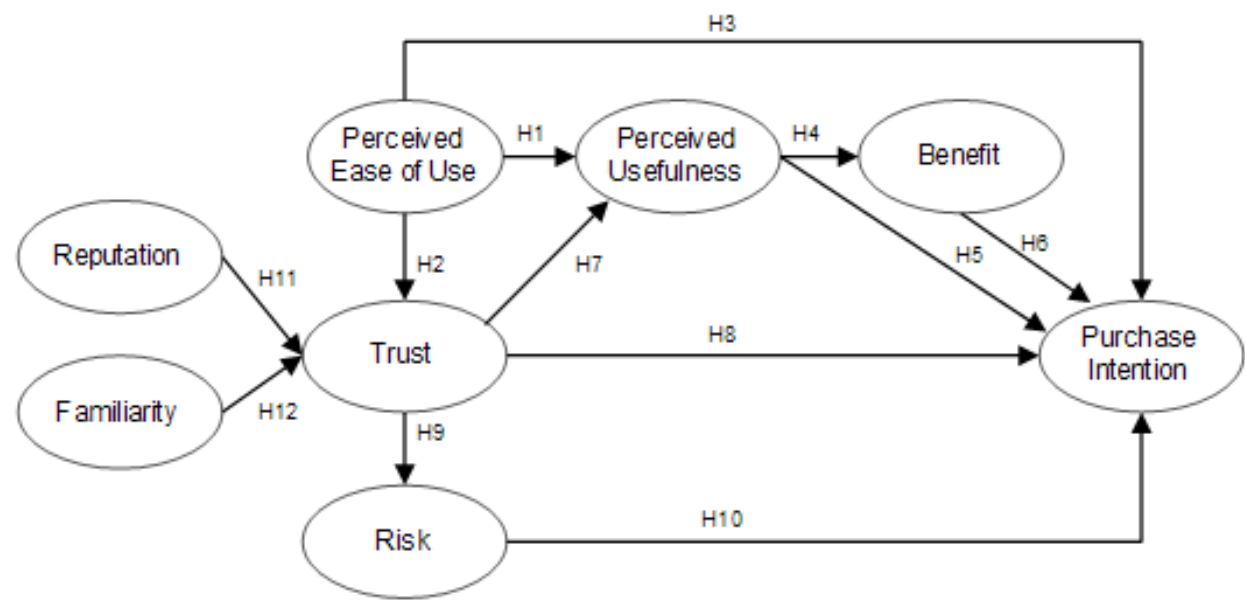

Figure 1. Proposed research model

\section{Research method}

\subsection{Sample and data collection}

This research surveyed consumers of $\mathrm{C} 2 \mathrm{C}$ e-commerce in Indonesia. An online, self-administered survey was intended to explore the customer purchase intention towards $\mathrm{C} 2 \mathrm{C}$ e-commerce websites. The web-survey procedure is utilized since its give a few advantages, for example, saving time and money, access to an extensive population of individual, interactive, and dynamic components that 
increase respondent inspiration to answer the inquiries, and ease of approaching particular targets (Schmidt, 1997). The instructions for the questionnaire stated that this study sought to investigate the purchase intention of online shopper. To generalize our findings, we assigned three $\mathrm{C} 2 \mathrm{C}$ online shopping company's websites in Indonesia which at least one of them is frequently used for online shopping by the respondents. The rank of the companies investigated in this research according to ecommerceIQ, based on top websites categorized under shopping category are as follow: Company A, Company B, and Company C. The comparison of the three C2C e-commerce company are shown in Table 1.

\begin{tabular}{|c|c|c|c|c|}
\hline No & Company & $\mathbf{A}$ & B & C \\
\hline 1. & Location & Indonesia & Indonesia & Indonesia \\
\hline 2. & $\begin{array}{l}\text { Type } \\
\text { information } \\
\text { available on the } \\
\text { website }\end{array}$ & $\begin{array}{l}\text { Seller grades (positive, negative, } \\
\text { and neutral); percentage of } \\
\text { successful transaction; amount of } \\
\text { sold products; sellers review; } \\
\text { quality and accuracy of product; } \\
\text { and discussion forum. }\end{array}$ & $\begin{array}{l}\text { Product details, wholesale } \\
\text { price, amount of sold } \\
\text { products, product review, } \\
\text { seller review, percentage of } \\
\text { successful transaction, amount } \\
\text { of customer. }\end{array}$ & $\begin{array}{l}\text { Product details, product } \\
\text { review, discussion forum, } \\
\text { product return information, } \\
\text { product stock available. }\end{array}$ \\
\hline 3. & $\begin{array}{l}\text { Product } \\
\text { category }\end{array}$ & $\begin{array}{l}\text { Fashion } \\
\text { (women/man/moeslem/kids); } \\
\text { beauty; health; mom and kids; } \\
\text { household; handphone \& tablet; } \\
\text { laptop \& accessories; computer \& } \\
\text { acesories; electronics; camera; } \\
\text { automotive; sports; } \\
\text { film/music/games; kitchen; offce } \\
\text { and stationery; souvernir; toys \& } \\
\text { hobbies; books; software; other } \\
\text { products. }\end{array}$ & $\begin{array}{l}\text { Fashion (women/man); } \\
\text { beauty and health; } \\
\text { handphone; computer; } \\
\text { electronics; camera; hobby \& } \\
\text { collection; sports; bycycle; } \\
\text { kids fashion; mother \& baby; } \\
\text { perlengkapan bayi; home } \\
\text { appliances; food; car parts \& } \\
\text { accesories; motorcycle; } \\
\text { industrial. }\end{array}$ & $\begin{array}{l}\text { Fashion; beauty/ health; } \\
\text { mother \& baby; perlatan } \\
\text { bayi dan anak; home } \\
\text { appliances; } \\
\text { gadget/computer; } \\
\text { electronics; } \\
\text { sports/hobby/automotive; } \\
\text { service. }\end{array}$ \\
\hline 4. & $\begin{array}{l}\text { Reputation of } \\
\text { the sellers }\end{array}$ & $\begin{array}{l}\text { The reputation of the sellers } \\
\text { calculated based on points given } \\
\text { by customers which will } \\
\text { determine the seller badge (from } \\
\text { low to high: bronze, silver, and } \\
\text { gold). }\end{array}$ & $\begin{array}{l}\text { The reputation of the sellers } \\
\text { calculated based on positive } \\
\text { feedback by customer which } \\
\text { will determine the seller's } \\
\text { badge (from low to high: } \\
\text { bronze, silver, and gold). }\end{array}$ & $\begin{array}{l}\text { The reputation of the } \\
\text { sellers calculated based on } \\
\text { the accumulation of } \\
\text { transactions with customers } \\
\text { shown by the badge level } \\
\text { (basic, bronze, gold, } \\
\text { platinum). }\end{array}$ \\
\hline 5. & Logistic Partner & 12 logistic partner & 8 logistic partner & 10 logistic partner \\
\hline
\end{tabular}

Table 1. Details of the three C2C companies

\subsection{Measures}

The research model was developed using literature studies and expert judgment of five (5) experts in the e-commerce field to verify the research model and to choose the relationship of variables which suitable for the condition of Indonesia. The questionnaires from experts are collected using 5 Lickert scales. The relationship of latent variables will be accepted when the geomean value more than 3.5 
(Mohaparta, Mohantry \& Dhalla, 2010). The result of expert assessment and literature study are the basis for the research model with 12 hypothesis which will be measured in this research.

The questionnaire used to test the relationship of the variables are distributed to the experienced online shopper in at least one of three online websites (Company A, B, or C). A pilot study was led to test the legitimacy of the survey to 40 undergraduate students. Items measuring purchase intention also use five-point Lickert scale (1 describes "strongly disagree" until 5 describes "strongly agree"). Table 2 shows indicators or item used for the questionnaire.

\subsection{Data analysis method}

This research was developed using structural equation modeling, a multivariate analysis approach which simultaneously used to examine and estimates complex causal relationship among variables (Williams, Vanderberg \& Edwards, 2009). This study utilizes AMOS 22 to conduct SEM analysis. This study adopted two steps analysis procedure (measurement and structural model) and maximum likelihood (Anderson, 1988). To start with, this research performed a confirmatory factor analysis to assess the fit and develop validity of the model estimation. The second step is conducted once the satisfactory factor of measurement model is obtained (Bollen, Structural Equation Modelling with Latent Variables, 1989).

The total amount of collected data came from 1254 respondents. The data underwent rigorous outliers deletion through Mahalanobis distance detection. The remaining data processed is 400 data for each company or in a total of 1200 data. Further, univariate normality was analyzed using the Z-statistic skewness and kurtosis. The result shows the data already follows a normal distribution.

\section{Results}

\subsection{Demographics of the respondents}

Demographics of 1200 respondents in this study is shown in Table 3. The data shows $67 \%$ of them are females; $52.75 \%$ age below 20 years old; the latest education of $60.58 \%$ them are high school; $38.92 \%$ of them shop online for once in a month; $58.58 \%$ of them have estimated money for online shopping ranged from Rp. 100,000 - Rp 25,000 (\$10 - \$25). The frequency of online shopping and estimated money spent are heterogeneous, and this reveals a different behavior of online shopping of the respondents. 


\begin{tabular}{|c|c|c|}
\hline Constructs & Measurement Items & Adapted From \\
\hline \multirow{5}{*}{$\begin{array}{l}\text { Perceived ease } \\
\quad \text { of use }\end{array}$} & This website is easy-to-use. & $\begin{array}{l}\text { (Gefen, 2000; Heijden, Verhagen \& Creemers ,2003; Venkatesh, } \\
\text { 2000; Pavlou, 2003; Gefen et al., 2003) }\end{array}$ \\
\hline & Learning to operate this website is easy. & (Gefen, 2000; Gefen et al., 2003; Heijden et al., 2003) \\
\hline & $\begin{array}{l}\text { The interaction with this website is clear and easy } \\
\text { to understand. }\end{array}$ & $\begin{array}{l}\text { (Gefen, 2000; Heijden et al., 2003; Venkatesh, 2000; Pavlou, 2003; } \\
\text { Gefen et al., 2003) }\end{array}$ \\
\hline & $\begin{array}{l}\text { I find that its simple to find the data that I need in } \\
\text { this present retailer's Web website. }\end{array}$ & (Pavlou, 2003) \\
\hline & $\begin{array}{l}\text { I find it simple to get the sytem to do what I need } \\
\text { it to do. }\end{array}$ & (Heijden et al., 2003; Venkatesh; 2000) \\
\hline \multirow{5}{*}{$\begin{array}{l}\text { Perceived } \\
\text { usefulness }\end{array}$} & Purchase online is easy on this website. & (Gefen, 2000; Heijden, et al. 2003) \\
\hline & Purchase online in this website is fast. & (Gefen, 2000; Gefen et al., 2003; Heijden et al., 2003) \\
\hline & $\begin{array}{l}\text { This website improves my performance in } \\
\text { searching and buying products }\end{array}$ & (Gefen, 2000; Gefen et al., 2003; Venkatesh, 2000) \\
\hline & $\begin{array}{l}\text { This website enhances my effectiveness in } \\
\text { searching and buying products. }\end{array}$ & (Gefen, 2000; Gefen et al., 2003; Venkatesh, 2000) \\
\hline & The content on this website is useful to me. & (Heijden et al., 2003; Pavlou, 2003; Venkatesh, 2000) \\
\hline \multirow{4}{*}{ Trust } & This site is trustworthy. & $\begin{array}{l}\text { (Kim et al., 2008; Heijden et al., 2003; Javernpaa et al., 2000; } \\
\text { Pavlou, 2003) }\end{array}$ \\
\hline & $\begin{array}{l}\text { This site gives the feeling that it keeps guarantees } \\
\text { and responsibilities }\end{array}$ & $\begin{array}{l}\text { (Kim et al., 2008; Gefen, 2000; Heijden et al., 2003; Javernpaa et al., } \\
\text { 2000; Pavlou, 2003) }\end{array}$ \\
\hline & This store's behavior meets my expectations & (Heijden et al., 2003; Javernpaa et al., 2000) \\
\hline & I believe this site keeps my best selection in mind. & (Kim et al., 20008; Javernpaa et al., 2000; Pavlou, 2003) \\
\hline \multirow{5}{*}{ Benefit } & I think utilizing this Website is helpful. & \multirow{5}{*}{ (Kim et al., 2008) } \\
\hline & $\begin{array}{l}\text { I can spare cash by utilizing this Website for } \\
\text { internet shopping. }\end{array}$ & \\
\hline & I can spare time by utilizing this Website. & \\
\hline & $\begin{array}{l}\text { Utilizing this Website empowers me to finish a } \\
\text { shopping errand more rapidly than utilizing } \\
\text { conventional stores. }\end{array}$ & \\
\hline & $\begin{array}{l}\text { Utilizing this Website builds my efficiency in } \\
\text { shopping (e.g., settle on buy choices or discover } \\
\text { item data rapidly). }\end{array}$ & \\
\hline \multirow[t]{2}{*}{ Risk } & $\begin{array}{l}\text { Buying from this Website would include more } \\
\text { financial risk (i.e.fraud, difficult to return) when } \\
\text { compared with more conventional methods for } \\
\text { shopping). }\end{array}$ & $\begin{array}{l}\text { (Kim et al., 2008; Heijden et al., 2003; Javernpaa et al., 2000; } \\
\text { Pavlou, 2003) }\end{array}$ \\
\hline & $\begin{array}{l}\text { How would you rate your overall perception of } \\
\text { risk from this site? }\end{array}$ & $\begin{array}{l}\text { (Kim et al., 2008; Heijden et al., 2003; Javernpaa et al., 2000; } \\
\text { Pavlou, 2003) }\end{array}$ \\
\hline \multirow{3}{*}{ Reputation } & This Website is well known. & (Kim et al., 2008; Javernpaa et al., 2000) \\
\hline & This Website has a good reputation. & (Kim et al., 2008; Javerpaa et al., 2000; Pavlou, 2003) \\
\hline & $\begin{array}{l}\text { This Website vendor has a reputation for being } \\
\text { honest. }\end{array}$ & (Kim et al., 2008; Pavlou, 2003) \\
\hline \multirow{4}{*}{ Familiarity } & Overall, I am familiar with this site. & (Kim et al., 2008; Gefen et al., 2003) \\
\hline & I am familiar with items searching on this website. & (Kim et al., 2008; Gefen, 2000) \\
\hline & $\begin{array}{l}\text { I am familiar with purchasing process from this } \\
\text { site. }\end{array}$ & (Kim et al., 2008; Gefen, 2000) \\
\hline & $\begin{array}{l}\text { I am familiar with buying products from this } \\
\text { website. }\end{array}$ & (Kim et al., 20008) \\
\hline \multirow{5}{*}{$\begin{array}{l}\text { Purchase } \\
\text { intention }\end{array}$} & $\begin{array}{l}\text { I am probably going to buy the products on this } \\
\text { site. }\end{array}$ & $\begin{array}{l}\text { (Kim et al., 2008; Gefen, 2000; Heijden et al., 2003; Javernpaa et al., } \\
2000)\end{array}$ \\
\hline & $\begin{array}{l}\text { I am probably going to recommend this site to my } \\
\text { companions. }\end{array}$ & (Kim et al., 2008) \\
\hline & $\begin{array}{l}\text { I would not hesitate to provide information to this } \\
\text { website }\end{array}$ & (Gefen, 2000; Gefen et al., 2003) \\
\hline & I would utilize my credit card to buy from this site & (Gefen, 2000; Gefen et al., 2003) \\
\hline & $\begin{array}{l}\text { It is likely that I will transact with this web retailer } \\
\text { in the future }\end{array}$ & $\begin{array}{l}\text { (Dehua, Lu \& Zhou, 2008; Kim et al., 2008; Heijden et al., 2003; } \\
\text { Javernpaa et al., 2000; Pavlou, 2003; Venkatesh, 2000) }\end{array}$ \\
\hline
\end{tabular}

Table 2. Proposed measurement items for constructs 


\begin{tabular}{|c|c|c|}
\hline Questions & Count & Percentage \\
\hline \multicolumn{3}{|l|}{ Age (Years) } \\
\hline$<20$ & 633 & 52.75 \\
\hline $20-30$ & 551 & 45.92 \\
\hline $31-40$ & 15 & 1.25 \\
\hline$>40$ & 1 & 0.08 \\
\hline \multicolumn{3}{|l|}{ Gender } \\
\hline Male & 387 & 32.25 \\
\hline Female & 813 & 67.75 \\
\hline \multicolumn{3}{|l|}{ Latest Education } \\
\hline High school & 727 & 60.58 \\
\hline Some college/ vocational school & 82 & 6.83 \\
\hline Bachelor degree & 381 & 31.75 \\
\hline Master degree & 10 & 0.83 \\
\hline \multicolumn{3}{|l|}{ Frequency of online shopping } \\
\hline$>$ Once in a week & 53 & 4.42 \\
\hline Once in a week & 69 & 5.75 \\
\hline Once in two weeks & 136 & 11.33 \\
\hline$>$ Once in a month & 9 & 0.75 \\
\hline Once in a month & 466 & 38.83 \\
\hline$<$ Once in a month & 467 & 38.92 \\
\hline \multicolumn{3}{|c|}{ Estimated money spent on online shopping } \\
\hline$<$ Rp. 100,000 & 230 & 19.17 \\
\hline Rp. 100,000 - Rp. 250,000 & 703 & 58.58 \\
\hline Rp. 250,000 - Rp. 500,000 & 201 & 16.75 \\
\hline Rp. 500,000 - Rp. 750,000 & 32 & 2.67 \\
\hline Rp. 750,000 - Rp. $1,000,000$ & 17 & 1.42 \\
\hline$>$ Rp. $1,000,000$ & 17 & 1.42 \\
\hline
\end{tabular}

Table 3. Demographic characteristic of respondents

\subsection{Construct validity and reliability}

Construct validity is measured by calculating Average Variance Extracted (AVE) of latent variable. AVE aims to test the variance in the measurement model of a variable by calculating the variance of the indicator. The acceptable AVE value requirement is above 0.5 (Fornell \& Larcker, 1981). Reliability test aims to test the internal consistency of a variable whether the selected indicators are reliable to measure latent variables. It is measured by calculating the value of Composite Reliability (CR). CR values of 0.6 to 0.7 are acceptable (Nunnally \& Bernstein, 1994).

The AVE of all constructs exceeds 0.5 which shows the validity of the constructs are acceptable. The CR of all constructs also exceeds 0.7 which showed adequate levels of reliability. Table 4 shows the values of $A V E$ and $C R$ indicating that measured variables are appropriate in measuring latent variables. 


\begin{tabular}{|l|r|r|r|r|r|r|}
\hline \multirow{2}{*}{ Variable } & \multicolumn{3}{|c|}{ AVE } & \multicolumn{3}{c|}{ CR } \\
\cline { 2 - 7 } & $\begin{array}{c}\text { Company } \\
\text { A }\end{array}$ & Company B & Company C & Company A & Company B & Company C \\
\hline Perceived ease of use & 0.63 & 0.609 & 0.697 & 0.901 & 0.878 & 0.897 \\
\hline Perceived usefulness & 0.584 & 0.612 & 0.632 & 0.87 & 0.862 & 0.866 \\
\hline Trust & 0.603 & 0.608 & 0.607 & 0.874 & 0.862 & 0.847 \\
\hline Benefit & 0.504 & 0.532 & 0.608 & 0.802 & 0.795 & 0.835 \\
\hline Risk & 0.541 & 0.625 & 0.697 & 0.763 & 0.8 & 0.816 \\
\hline Reputation & 0.594 & 0.603 & 0.599 & 0.896 & 0.88 & 0.856 \\
\hline Familiarity & 0.631 & 0.671 & 0.671 & 0.927 & 0.92 & 0.912 \\
\hline Purchase intention & 0.576 & 0.608 & 0.668 & 0.814 & 0.825 & 0.835 \\
\hline
\end{tabular}

Table 4. Construct validity and reliability measurements

\subsection{Hypothesis testing and model fit}

The structural model is tested to investigate the overall fit of the model to see the relationship between independent and dependent variables contained in the structural model. Confirmatory factor analysis is conducted to test for goodness of fit. The GOF lists utilized as a part of this study are absolute fit indicies and incremental fit indicies. Absolute fit indices used are Root Mean Square Error of Approximation (RMSEA), Standardized Root Mean Square Residual (SRMR) and CMIN/df (Lei \& Wu, 2007). Meanwhile, incremental fit indices used in this study are Normed Fit Index (NFI) and Comparative Fit Index (CFI) (Hooper, Coughlan \& Mullen, 2008). Table 5 shows Goodness of Fit (GOF) indices of the model.

\begin{tabular}{|l|r|r|r|r|}
\hline \multicolumn{1}{|c|}{$\begin{array}{c}\text { Goodness of Fit } \\
\text { Indexes }\end{array}$} & $\begin{array}{c}\text { Minimum } \\
\text { Value }\end{array}$ & Company A & Company B & Company C \\
\hline RMSEA & $<0.08$ & 0.056 & 0.058 & 0.057 \\
\hline SRMR & $<0.08$ & 0.052 & 0.048 & 0.051 \\
\hline CMIN/DF & $<3$ & 2.254 & 2.335 & 1.957 \\
\hline NFI & $>0.8$ & 0.84 & 0.848 & 0.843 \\
\hline CFI & $>0.9$ & 0.904 & 0.906 & 0.916 \\
\hline
\end{tabular}

Table 5. The Goodness of Fit (GOF) indices of the model

The results of the structural model showed that there is an acceptable fit between the proposed model and the data. Hence, each hypothesis testing results are obtained by examining the path significance. A model estimation for each of the companies is provided in Table 6. The value in the table is the computed standardized path coefficient estimation. 


\begin{tabular}{|c|c|c|c|c|c|c|}
\hline \multirow[b]{2}{*}{ Hypothesis } & \multirow{2}{*}{\multicolumn{3}{|c|}{ Paths }} & Company A & Company B & Company C \\
\hline & & & & $\begin{array}{c}\text { Standardized } \\
\text { Path } \\
\text { Coefficient }\end{array}$ & $\begin{array}{c}\text { Standardized } \\
\text { Path } \\
\text { Coefficient }\end{array}$ & $\begin{array}{c}\text { Standardized } \\
\text { Path } \\
\text { Coefficient }\end{array}$ \\
\hline $\mathrm{H} 1$ & $\begin{array}{l}\text { Perceived ease } \\
\text { of use }\end{array}$ & $\rightarrow$ & $\begin{array}{l}\text { Perceived } \\
\text { usefulness }\end{array}$ & $0.54^{*}$ & $0.67 *$ & $0.54 *$ \\
\hline $\mathrm{H} 2$ & $\begin{array}{l}\text { Perceived ease } \\
\text { of use }\end{array}$ & $\rightarrow$ & Trust & $0.50 *$ & $0.25^{* *}$ & $0.33 *$ \\
\hline H3 & $\begin{array}{l}\text { Perceived ease } \\
\text { of use }\end{array}$ & $\rightarrow$ & $\begin{array}{l}\text { Purchase } \\
\text { intention }\end{array}$ & $0.32^{* * *)}$ & $\left.-0.53^{* * *}\right)$ & $\left.-2.59^{* * *}\right)$ \\
\hline $\mathrm{H} 4$ & $\begin{array}{l}\text { Perceived } \\
\text { usefulness }\end{array}$ & $\rightarrow$ & Benefit & $0.9^{*}$ & $0.98^{*}$ & $0.83^{*}$ \\
\hline H5 & $\begin{array}{l}\text { Perceived } \\
\text { usefulness }\end{array}$ & $\rightarrow$ & $\begin{array}{l}\text { Purchase } \\
\text { intention }\end{array}$ & $\left.-0.2^{* * *}\right)$ & $0.81 *$ & $\left.5.80^{* * *}\right)$ \\
\hline H6 & Benefit & $\rightarrow$ & $\begin{array}{l}\text { Purchase } \\
\text { intention }\end{array}$ & $\left.0.23^{* * *}\right)$ & $\left.0.41^{* * *}\right)$ & $0.30 * *$ \\
\hline $\mathrm{H} 7$ & Trust & $\rightarrow$ & $\begin{array}{l}\text { Perceived } \\
\text { usefulness }\end{array}$ & $0.46^{*}$ & $0.39 *$ & $0.58^{*}$ \\
\hline $\mathrm{H} 8$ & Trust & $\rightarrow$ & $\begin{array}{l}\text { Purchase } \\
\text { intention }\end{array}$ & $0.43^{* *}$ & $\left.0.04^{* * *}\right)$ & $\left.-3.27^{* * *}\right)$ \\
\hline H9 & Trust & $\rightarrow$ & Risk & $0.61 *$ & $0.69 *$ & $0.73^{*}$ \\
\hline $\mathrm{H} 10$ & Risk & $\rightarrow$ & $\begin{array}{l}\text { Purchase } \\
\text { intention }\end{array}$ & $0.15^{* *}$ & $\left.0.13^{* * *}\right)$ & $\left.0.15^{* * *}\right)$ \\
\hline H11 & Reputation & $\rightarrow$ & Trust & $0.39 *$ & $0.70^{*}$ & $0.56^{*}$ \\
\hline $\mathrm{H} 12$ & Familiarity & $\rightarrow$ & Trust & $\left.0.09^{* * *}\right)$ & $\left.0.0001^{* * *}\right)$ & $\left.0.22^{* * *}\right)$ \\
\hline
\end{tabular}

Note:* significant at $\mathrm{p}<.001 ;{ }^{* *}$ significant at $\left.\mathrm{p}<.05 ; * * *\right)$ not significant path

Table 6. SEM estimation results

The results of hypothesis testing conducted on the three companies show that trust $(\beta 8: 0.43 ; \mathrm{p}<0.05)$ and risk $(\beta 10: 0.15 ; \mathrm{p}<0.05)$ affecting purchase intention significantly in company $\mathrm{A}$. The significant relationship between trust and risks is consistent with the previous studies suggesting that trust would be a risk-reducing factor in online transaction (Pavlou, 2003). Although the TAM factors (perceived ease of use and perceived usefulness) not directly change purchase intention, the perceived ease of use factor significantly affects trust at $\mathrm{p}<0.001$ which indicates that the relationship between these two factors shows that trust in Company A comes from ease of use. The structural model with the estimation value of company A is shown in Figure 2.

Perceived usefulness is a factor that directly and significantly affects purchase intention in the company B ( $\beta 5$ : 0.81; $\mathrm{p}<0.001)$. Perceived usefulness, in this context such as the effectiveness of searching for products, useful website content, and relatively fast purchasing process. The perceived usefulness comes from several significant antecedents factors, such as trust and ease of use. Usefulness will be perceived by the customer once the customer experienced particular website is easy to use, and the trust of customer for the website already exists, thus supporting Hypothesis $1(\beta 1: 0.67 ; \mathrm{p}<0.001)$ and Hypothesis 7 ( $\beta 7: 0.39 ; \mathrm{p}<0.001)$. The insignificant relationship of trust to purchase intention indicates 
that customer's trust on company B website is not fully developed and not yet enough to influence purchase intention. The structural model with the estimation value of company B is shown in Figure 3.

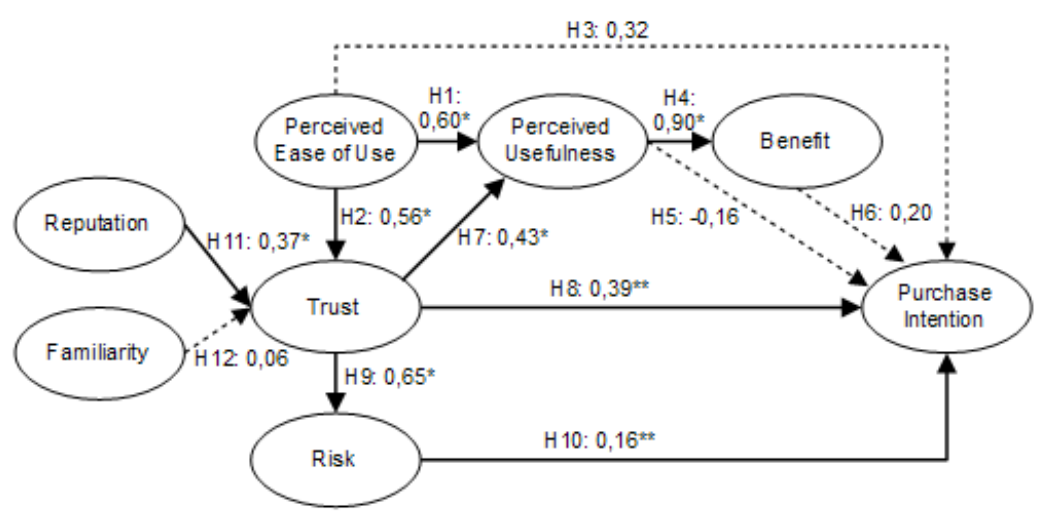

Note: $\rightarrow$ significant path; ---> insignificant path

Figure 2. Structural model of company A

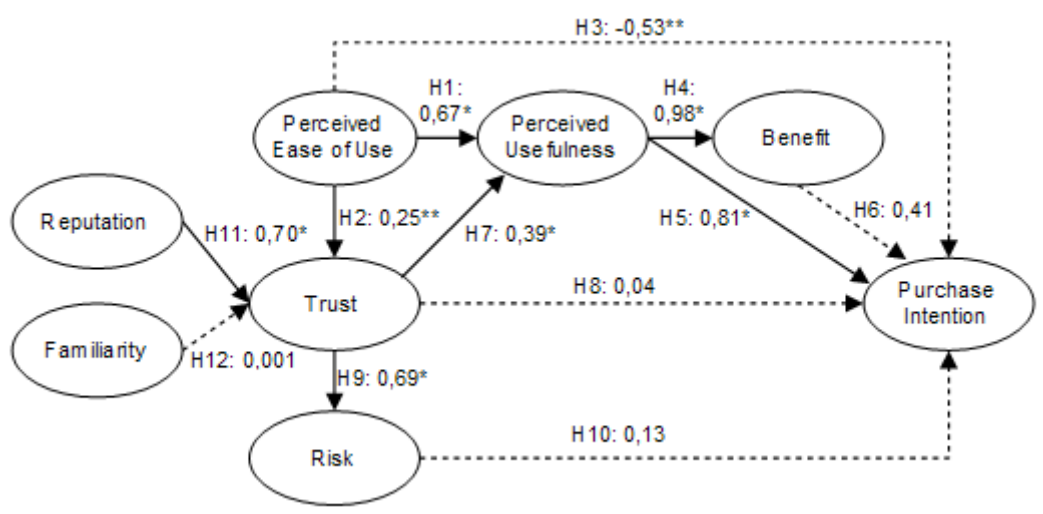

Figure 3. Structural model of company B

Company $\mathrm{C}$ sees the benefit as a factor affecting purchase intention of the customers significantly ( $\beta$ 6: 0.30; $\mathrm{p}<0.05)$. It is also found that trust and risk factors are not significant factors in influencing customer purchase intention at website C. In other words, customer confidence has not been sufficient to influence customers to make a purchase. The TAM factors (ease of use and perceived usefulness) in company $\mathrm{C}$ does not significantly affect customer's purchase intention which inconsistent with research conducted in one of e-commerce C2C website in China (Dehua, Lu \& Zhou, 2008). The structural model with the estimation value of company $\mathrm{C}$ is shown in Figure 4. 


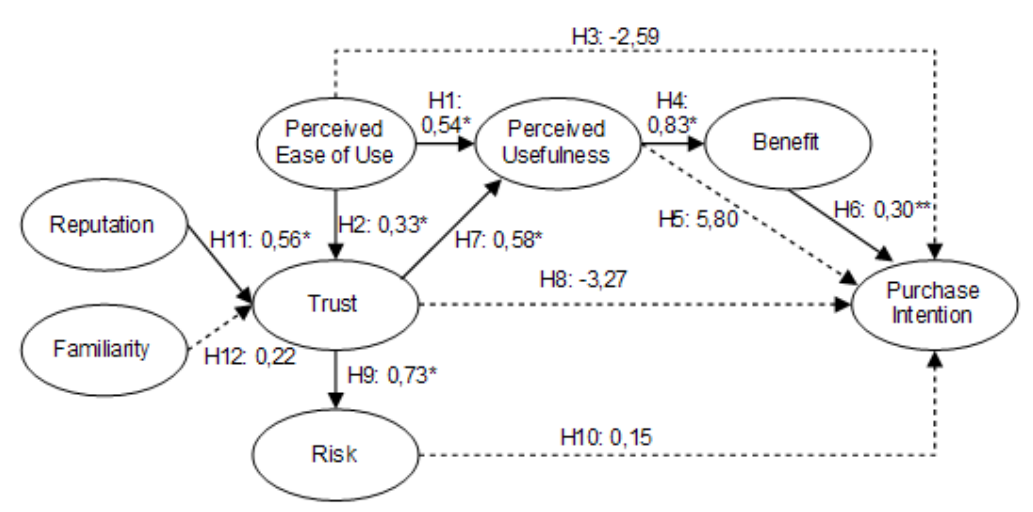

Figure 4. Structural model of company C

The hypothesis testing results in this study are shown in Table 7. In company A, eight hypotheses were supported. Meanwhile, in each of company B and C, seven hypothesis are supported.

In order to test the importance of a variable, the total effect value of a latent variable is u sed (Kim, Kaplowitz and Johnston (2004). The Effects of Physician Empathy on Patient Satisfaction and Compliance. Evaluation \& The Health Professions, 27(3), 237-251. 2004). The value of direct effect is equal to path coefficient value. The indirect effect analysis and the total effect of a variable are also taken into consideration in the customer's purchase intention model. Table 8 shows the value of direct effect, indirect effect, and total effect of each variable towards purchase intention.

\begin{tabular}{|c|c|c|c|c|c|c|}
\hline Hypothesis & \multicolumn{3}{|c|}{ Paths } & Company A & Company B & Company C \\
\hline H1 & $\begin{array}{l}\text { Perceived ease } \\
\text { of use }\end{array}$ & $\rightarrow$ & $\begin{array}{l}\text { Perceived } \\
\text { usefulness }\end{array}$ & Supported & Supported & Supported \\
\hline $\mathrm{H} 2$ & $\begin{array}{l}\text { Perceived ease } \\
\text { of use }\end{array}$ & $\rightarrow$ & Trust & Supported & Supported & Supported \\
\hline $\mathrm{H} 3$ & $\begin{array}{l}\text { Perceived ease } \\
\text { of use }\end{array}$ & $\rightarrow$ & $\begin{array}{l}\text { Purchase } \\
\text { intention }\end{array}$ & Not Supported & Not supported & Not supported \\
\hline $\mathrm{H} 4$ & $\begin{array}{l}\text { Perceived } \\
\text { usefulness }\end{array}$ & $\rightarrow$ & Benefit & Supported & Supported & Supported \\
\hline H5 & $\begin{array}{l}\text { Perceived } \\
\text { usefulness }\end{array}$ & $\rightarrow$ & $\begin{array}{l}\text { Purchase } \\
\text { intention }\end{array}$ & Not Supported & Supported & Not supported \\
\hline H6 & Benefit & $\rightarrow$ & $\begin{array}{l}\text { Purchase } \\
\text { intention }\end{array}$ & Not Supported & Not supported & Supported \\
\hline $\mathrm{H} 7$ & Trust & $\rightarrow$ & $\begin{array}{l}\text { Perceived } \\
\text { usefulness }\end{array}$ & Supported & Supported & Supported \\
\hline H8 & Trust & $\rightarrow$ & $\begin{array}{l}\text { Purchase } \\
\text { intention }\end{array}$ & Supported & Not supported & Not supported \\
\hline $\mathrm{H} 9$ & Trust & $\rightarrow$ & Risk & Supported & Supported & Supported \\
\hline H10 & Risk & $\rightarrow$ & $\begin{array}{l}\text { Purchase } \\
\text { intention }\end{array}$ & Supported & Not supported & Not supported \\
\hline H11 & Reputation & $\rightarrow$ & Trust & Supported & Supported & Supported \\
\hline $\mathrm{H} 12$ & Familiarity & $\rightarrow$ & Trust & Not Supported & Not supported & Not supported \\
\hline
\end{tabular}

Table 7. Summary of hypothesis testing 
Ease of use is the factor with the highest total effect on company A. Although ease of use insignificantly affects customer purchase intention, ease of use is one of the antecedents factors of trust which is significant to affect customer's purchase intention. In the company B, perceived usefulness has the highest total effect value. Perceived usefulness is a significant factor affecting customer's purchase intention with a high indirect effect value (0.405). In the company $\mathrm{C}$, the perceived usefulness of the customer is the factor that has the highest total effect so that it becomes the top priority as one of the factors to increase customer's purchase intention.

\begin{tabular}{|l|r|r|r|r|r|r|r|r|r|}
\hline \multirow{2}{*}{$\begin{array}{c}\text { Latent } \\
\text { Variable }\end{array}$} & \multicolumn{3}{|c|}{ Company A } & \multicolumn{3}{c|}{ Company B } & \multicolumn{3}{c|}{ Company C } \\
\cline { 2 - 10 } & \multicolumn{1}{|c|}{ Effect } & $\begin{array}{c}\text { Indirect } \\
\text { Effect }\end{array}$ & $\begin{array}{c}\text { Total } \\
\text { Effect }\end{array}$ & $\begin{array}{c}\text { Direct } \\
\text { Effect }\end{array}$ & $\begin{array}{c}\text { Indirect } \\
\text { Effect }\end{array}$ & $\begin{array}{c}\text { Total } \\
\text { Effect }\end{array}$ & $\begin{array}{c}\text { Direct } \\
\text { Effect }\end{array}$ & $\begin{array}{c}\text { Indirect } \\
\text { Effect }\end{array}$ & $\begin{array}{c}\text { Total } \\
\text { Effect }\end{array}$ \\
\hline $\begin{array}{l}\text { Perceived ease } \\
\text { of use }\end{array}$ & 0.321 & 0.264 & 0.585 & -0.539 & 0.974 & 0.434 & $-2,599$ & 3.423 & 0.824 \\
\hline $\begin{array}{l}\text { Perceived } \\
\text { usefulness }\end{array}$ & -0.206 & 0.207 & 0.001 & 0.814 & 0.405 & 1.219 & 5.805 & 0.258 & 6.063 \\
\hline Trust & 0.431 & 0.094 & 0.525 & 0.043 & 0.575 & 0.618 & -3.272 & 3.647 & 0.375 \\
\hline Benefit & 0.23 & 0 & 0.23 & 0.412 & 0 & 0.412 & 0.309 & 0 & 0.309 \\
\hline Risk & 0.152 & 0 & 0.152 & 0.13 & 0 & 0.13 & 0.157 & 0 & 0.157 \\
\hline Reputation & 0 & 0.206 & 0.206 & 0 & 0.434 & 0.434 & 0 & 0.211 & 0.211 \\
\hline Familiarity & 0 & 0.049 & 0.049 & 0 & 0 & 0 & 0 & 0.037 & 0.037 \\
\hline
\end{tabular}

Table 8. Direct Effect, indirect effect, and total effect of variable towards customer's purchase intention

\subsection{Comparison analysis of the three companies}

Based on the demographics of respondents, the estimated expense of more than seven hundred and fifty thousand rupiahs or $\$ 75$ is mostly occur in Company A which shows that the level of trust in Company A is higher than Company B and C. In Company B, although the level of trust has not been as high as Company A, perceived usefulness factor is good enough so that the transaction value above seven hundred fifty thousand rupiahs is still higher than Company C. Benefit is a dominant factor in Company $\mathrm{C}$ which shapes customer's intention to make a purchase.

The frequency of online shopping once a week in the Company A is higher than in B and C. This repeated purchase indicates that risk becomes one of buyer's considerations to make a purchase. The high frequency of purchasing activity of customers in Company A shows that uncertainty of online shopping in Company A tends to be less than in company B and C.

Analysis of TAM theory in each company is compared with previous research. In Table 7, it is found that not all TAM components, such as Perceived Use (PU) and Perceived Ease of use (PEOU) influence purchase intention (PI) in accordance with the theory (Davis, 1989). However, the 
circumstances that occur in this study also occur in the previous study (Heijeden et al., 2003) where trust, PEOU, PU are insignificant because these variables are categorized as 'threshold' variables which are defined that once an evaluation level is obtained, these variables no longer contribute to behavioral intentions. Therefore, this variable will be significant at the low evaluation level or when the respondent evaluates the website as a bad category website. Illustration of this condition is described as follows, a buyer may purchase or not purchase on a user-friendly website, but the buyer definitely will not purchase on a website which is not user-friendly.

Another reason for the insignificant relationship of TAM variables is because the website selected in this study is not a website where the condition of PEOU and PU which have a bad evaluation. Therefore, the researchers speculate that PEOU and PU reach expectations levels in almost all respondents which become the reason why these variables do not affect customer's online purchase intention.

In each of the company, not all TAM variables are significant to purchase intention. The explanation of this result is because purchase intention more narrowly compared to the variables found in the TAM model in general, which is intention to use. The original TAM model focuses intention to use technology, which is different from purchase intention. In the context of e-commerce, usage intention is wider than purchase intention. This is because someone may be using an online website but not to buy, but also to obtain information about a product and service. In the context of e-commerce, intention to use is more extensive than purchase intention because somebody might utilize an online site but not to purchase and only acquire data about an item and administration. Therefore, respondents are not interested in buying products on online shopping websites even though they feel the website is useful.

In the three model of the company, there is similarity that the relationship of familiarity or not significant relationship to trust which is inconsistent with the previous research (Kim et al., 2008). The differences in this conditions define two possibilities. The first possibility, online shopping websites cognition of consumers in Indonesia is adequate so that it is not significant to affect customer's purchase intention. The second possibility is Indonesian do not only consider familiarity (i.e., the layout of website menu) when purchasing in online shopping websites, so that it is not significant enough to influence customer's purchase intention.

The summary of analysis based on path coefficient, direct effect, indirect effect, and total effect of factors in the research model are shown in Table 9. 


\begin{tabular}{|l|l|l|l|}
\hline \multicolumn{1}{|c|}{ Analysis } & \multicolumn{1}{|c|}{ Company A } & \multicolumn{1}{c|}{ Company B } & \multicolumn{1}{c|}{ Company C } \\
\hline $\begin{array}{l}\text { Significant factors } \\
\text { towards purchase } \\
\text { intention }\end{array}$ & Trust and risk & Perceived usefulness & Benefit \\
\hline $\begin{array}{l}\text { Significant antecedents } \\
\text { factors }\end{array}$ & $\begin{array}{l}\text { Perceived ease of } \\
\text { use and reputation }\end{array}$ & $\begin{array}{l}\text { Perceived Ease of Use, } \\
\text { reputation, and trust }\end{array}$ & $\begin{array}{l}\text { Perceived ease of use, } \\
\text { perceived usefulness, trust, and } \\
\text { reputation }\end{array}$ \\
\hline $\begin{array}{l}\text { Significant TAM } \\
\text { factors }\end{array}$ & PEOU $\rightarrow$ PU & $\begin{array}{l}\text { PEOU } \rightarrow \text { PU } \\
\text { PU } \rightarrow \text { Purchase intention }\end{array}$ & PEOU $\rightarrow$ PU \\
\hline $\begin{array}{l}\text { Important factors } \\
\text { based on total effects } \\
\text { value }\end{array}$ & $\begin{array}{l}\text { Perceived ease of } \\
\text { use }\end{array}$ & Perceived usefulness & Perceived usefulness \\
\hline
\end{tabular}

Table 9. Summary of comparison analysis of three companies

\section{Conclusion}

This study aims to investigate factors influencing consumer's purchase intention of e-commerce on three e-commerce $\mathrm{C} 2 \mathrm{C}$ company websites. Technology acceptance model was used as the guiding theory for this study.

The result based on five expert judgments, there are eight (8) latent variables and 33 indicators that influence customer purchase intention in C2C e-commerce sites in Indonesia. Using the regression values of the relationships of variables, it is found that trust and risk factors are factors that most significantly influence the purchase intention of customers in Company A. In company B, perceived usefulness is significant, while the benefits a significant factor which influences purchase intention in company C.

The shoppers in this research did not think much about the familiarity, but rather they cared about the reputation of the companies which prompts customer trust. Subsequently, it is suggested that sellers should give careful consideration to online shopping websites to increase customers' trust through website content, such as the content of information and more user-friendly website and also improve their customer services so that the reputation will attract more potential customers.

\section{References}

Anderson, J.C. (1988). Structural Equation Modeling in Practice: A Review and Recommend Two-Step Approach. Psychological Bulletin, 103(3), 411-423. https://doi.org/10.1037/0033-2909.103.3.411

Blau, P. (1989). Exchange and power social life. New York: Wiley. 
Bollen, K.A. (1989). Structural Equation Modeling with Latent Variables. New York: Wiley.

Chandio, F.H., Abbasi, M.S., Nizamani, H.A., \& Nizamani, Q.U. (2013). Online banking information systems acceptance: A structural equation modelling analysis. Journal of Business Information Systems, 32(7), 177-193. https://doi.org/10.1504/IJBIS.2013.052050

Chen, M.Y., \& Ching, I.T. (2013). A comprehensive model of the effects of online store image on purchase intention in an e-commerce environment. Electronic Commerce Research, 13(1), 1-23. https://doi.org/10.1007/s10660-013-9104-5

Dachyar, M., \& Hananto, L. (2014). Innovation and quality service factors to customer loyalty in Indonesia telecommunication company by using structural equation modeling method. Management and Technology in Knowledge, Service, Tourism \& Hospitality, 1, 41-44. https://doi.org/10.1201/b16700-10

Dachyar, M., \& Prasetya, M.D. (2012). Cloud Computing Implementation in Indonesia. International Journal of Applied Science and Technology, 2(3), 138-142.

Davis, F. (1989). Perceived Usefulness, perceived ease of use, and user acceptance of information technology. MIS Quarterly, 13(3), 319-339. https://doi.org/10.2307/249008

Dehua, H., Lu, Y., \& Zhou, D. (2008). Empirical Study of Customers' Purchase Intention in C2C Ecommerce. Tsinghua Science and Technology, 13(3), 287-292. https://doi.org/10.1016/S1007-0214(08)70046-4

Dishaw, M.T., \& Strong, D.M. (1999). Extending the technology acceptance model with tasktechnology fit constructs. Information \& Management, 36(1), 9-21.https://doi.org/10.1016/S03787206(98)00101-3

ecommerceIQ. (2017, April 11). Market Data: Indonesia. Retrieved from ecommerceIQ: https://ecommerceiq.asia/top-ecommerce-sites-indonesia/

eMarketer. (2016, September 2). Articles: Mobile and Internet Usage Propels Southeast Asia's Retail E-commerce Sector. Retrieved from eMarketer: https://www.emarketer.com/Article/Mobile-Internet-Usage-Propels-SoutheastAsias-Retail-Ecommerce-Sector/1014431

Fornell, C., \& Larcker, D.F. (1981). Evaluating Structural Equation Models with Unobservable Variables and Measurement Error. Journal of Marketing Research, 18(1), 39-50. https://doi.org/10.2307/3151312

Gefen, D. (2000). E-commerce: The Role of Familiarity and Trust. The International Journal of Management Science, 28, 725-737. https://doi.org/10.1016/S0305-0483(00)00021-9

Gefen, D., Karahanna, E., \& Straub, D.W. (2003). Trust and TAM in Online Shopping: An Integrated Model. Management Information System, 27(1), 51-90. https://doi.org/10.2307/30036519 
Heijden, H.V., Verhagen, T., \& Creemers, M. (2003). Understanding online purchase intentions: Contributions from technology and trust perpectives. European Journal of Information System, 12, 41-48. https://doi.org/10.1057/palgrave.ejis.3000445

Hongyao, N. (2013). Online Purchase Intention in B2C E-commerce: An Empirical Study. Wuhan International Conference on e-Business. Wuhan: WHICEB 2013 Proceedings.

Hooper, D., Coughlan, J., \& Mullen, M.R. (2008). Structural Equation Modelling: Guidelines for Determining Model Fit. The Electronic Journal of Business Research Methods, 6(1), 53-60.

Javernpaa, S.L., Tractinsky, N., \& Vitale, M. (2000). Consumer trust in an internet store. Infomation Technology and Management, 1, 45-71. https://doi.org/10.1023/A:1019104520776

Kim, D.J., Ferrin, D.L., \& Rao, H.R. (2008). A trust-based consumer decision-making model in electronic commerce: The role of trust, perceived risk, and their antecedents. Decision Support Systems, 44(2), 544-564. https://doi.org/10.1016/j.dss.2007.07.001

Kim, S.S., Kaplowitz, S., \& Johnston, M.V. (2004). The Effects of Physician Empathy on Patient Satisfaction and Compliance. Evaluation \& The Health Professions, 27(3), 237-251. https://doi.org/10.1177/0163278704267037

Kwahk, K.-Y., Ge, X., \& Park, J.H. (2012). Investigating the Determinants of Purchase Intention in C2C e-commerce. International Scholarly and Scientific Research \& Innovation, 6(9), 2378-2382.

Lei, P.W., \& Wu, Q. (2007). Introduction to Structural Equation Modelling Issues and Practical Considerations. Educational Measurement Issues and Practice, 26(3), 33-43 . https://doi.org/10.1111/j.17453992.2007.00099.x

Luhmann, N. (1979). Trust and Power. Chichester: Wiley.

Margherio, L. (1998). The emerging digital economy. Washington D.C: U.S Department of Commerce.

Mayer, R.C., Davis, J.H., \& Shoorman, F.D. (1995). An Integrative Model of Organizational Trust. The Academy of Management Review, 26(3), 709-734.

Mohaparta, R.K., Mohantry, R., \& Dhalla, R.S. (2010). Reengineering of logistics value chain of a petroleum products marketing company: Formulation of a Performance Measurement System. Proceedings of the 2010 International Conference on Industrial Engineering and Operations Management, 190196.

Nunnally, J.C., \& Bernstein, I.H. (1994). Psychometric theory (3rd Ed.). New York: Mc Graw-Hill. 
Pavlou, P.A. (2003). Consumer Acceptance of Electronic Commerce: Integrating Trust and Risk with Technology Acceptance Model. International Journal of Electronic Commerce, 7(3), 101-134.

Razdan, R., Das, M., \& Sohoni, A. (January, 2014). The Evolving Indonesian Consumer. Retrived from: https://www.mckinsey.com/business-functions/marketing-and-sales/our-insights/the-evolving-indonesian-consumer

Schmidt, W.C. (1997). World-Wide Web survey research: Benefits, potential problems, and solutions. Behaviour Research Methods, Instruments, \& Computers, 29(2), 274-279. https://doi.org/10.3758/BF03204826

Shih, H.P. (2004). An empirical study on predicting user acceptance of e-shopping on the web. Information \& Management, 41(93), 351-368. https://doi.org/10.1016/S0378-7206(03)00079-X

Statista (2016). e-Commerce. Retrieved October 20, 2016, from Statista: https://www.statista.com/outlook/243/120/e-commerce/indonesia\#

Venkatesh, V. (2000). Determinants of perceived ease of use: Integrating control, intrinsic motivation, and emotion into the technology acceptance model. Information system research, 46(2), 342-365. https://doi.org/10.1287/isre.11.4.342.11872

Williams, L.J., Vanderberg, R.J., \& Edwards, J.R. (2009). 12 Structural Equation Modelling in Management Research: A Guide for Improved Analysis. The Academy of Management Annals, 3, 543-604. https://doi.org/10.1080/19416520903065683

Zwass, V. (1998). Structure and macro-level impacts of electronic commerce: From technological infrastructure to electronic marketplaces. Thousand Oaks CA: McGraw-Hill. Retrieved March 9, 2017, from: http://www.mhhe.com/business/mis/zwass/ecpaper.html

Intangible Capital, 2017 (www.intangiblecapital.org) 